\title{
Perception of Prescribers and Pharmacists Regarding Traditional role of Community
} Pharmacists in Quetta, Pakistan

\author{
Muhammad Saood ${ }^{1}$, Noman Ul Haq*2, Aqeel Nasim³ ${ }^{3}$ Yasmin $\mathrm{Shah}^{4}$, Maria Tahir ${ }^{5}$
}

${ }^{1}$ M.Phil. Scholar, Department of Pharmacy Practice Faculty of Pharmacy and Health Sciences University of Balochistan Quetta, PAKISTAN

${ }^{2}$ Assistant Professor, Department of Pharmacy Practice Faculty of Pharmacy and Health Sciences University of Balochistan Quetta, PAKISTAN

${ }^{3}$ M.Phil. Pharmacy Practice, Hospital Pharmacist Balochistan Institute of Nephro Urology Quetta (BINUQ), PAKISTAN

${ }^{4}$ Pharm-D, Faculty of Pharmacy and Health Sciences University of Balochistan Quetta, PAKISTAN ${ }^{5}$ M.Phil. Pharmacy Practice, Sardar Bahadur Khan Women University Quetta, PAKISTAN

Received: 12 October, 2019

Accepted: 26 November,2019

*Correspondence to:

\section{Dr. Noman Ul Haq, PhD}

Email: nomanhaq79@gmail.com

Copyright: (C) the author(s), publisher and licensee Indian Academy of Pharmacists. This is an open-access article distributed under the terms of the Creative Commons Attribution Non-Commercial License, which permits unrestricted noncommercial use, distribution, and reproduction in any medium, provided the original work is properly cited.

Published by: OZZIE Publishers

\section{Abstract}

The purpose of this study was to investigate perception of pharmacist and prescriber regarding traditional role of community pharmacist. Questionnaire based, cross sectional study was conducted which comprised of 428 participants from Quetta, Pakistan. Majority $(n=242,56.5 \%)$ of respondents were prescribers while $(n=186$, $43.5 \%)$ were pharmacists with experience of $1-4$ years $(n=174,40.7 \%)$. Overall the majority $(n=386,90.2 \%)$ of the participants had positive perception regarding traditional dispensing and traditional counselling $(n=314,73.4 \%)$ role of community pharmacist. Concerning the prescribers, majority $(n=200,82.6 \%)$ had positive perception regarding traditional dispensing role and traditional counselling role $(n=132,524.5 \%)$ while concerning pharmacists, majority $(n=186,100 \%)$ had positive perception regarding the traditional dispensing role and traditional counselling $(n=182,97.8 \%)$ role of community pharmacist. This study concluded that both prescribers and pharmacists had positive perception regarding traditional role of community pharmacist, and it is recommended that further studies should be conducted regarding extended and clinical role of community pharmacist.

Key words: Prescriber, perception, community pharmacist, Quetta, Pakistan.

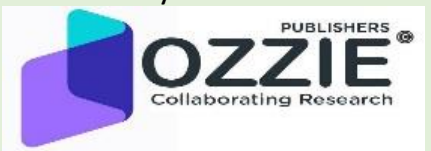

\begin{abstract}
INTRODUCTION
Community pharmacist being part of healthcare team and health care professional plays vital role in closing the gap that is between actual realized value and benefits of medicine and is the important member of comprehensive health care system [1]. Significant patient's care improvement can be achieved when different healthcare professionals collaborate according to their expertise [2].
\end{abstract}

The community pharmacist advices the patients regarding usage and possible effects of drugs prescribed to them by medical doctors and provides useful information regarding contraindications or medicines not to take with prescribed medication for having potential of causing drug interaction [3]. The community pharmacist is responsible to dispense the medication safely to public in general and to patient in specific and responsible to work under ethical standards [4]. Apart from just dispensing and supplying medications and consulting with HCPS and patients, the pharmacist also keeps the records of medication, patients and medical related products [3].

The increase in patient health demands, increase in chronic diseases and increase in diversity and complexity regarding role of community pharmacist in health system demands an up to date knowledge, expertise and skills to meet the needs of patient [1].

The role of pharmacist is different in different states of world according to their laws and implementation of laws, in some states pharmacists only have role in preparing and supplying/ dispensing of medications and in some states pharmacists have more focused role as sharing their expertise with medical doctors, patients and nurses [5]. 
The community pharmacists have great responsibilities to ensure the medication rational use and to achieve best possible outcomes perceived from the therapy. All these responsibilities start from supply chain of medicines, proper storage and quality preparation of medicines [6]. Pharmacist is also responsible to detect counterfeit, spurious, wrong labeling and falsified medicines. The community pharmacists are also having the responsibility to ensure that the prescription is proper or not, and to check whether the dosage form and dose regimens are appropriate, instruction regarding medicines usage is clear, any possible interaction like drug-drug or drugfood interactions prevented, ADRs predicted, contraindications and allergies are avoided, unnecessary medicines not prescribed and cost for treatment is considered [1].

The pharmacists also work to assist the patients by providing useful information regarding to their prescribed medications such information includes proper medicines intake and importance of medicines intake timely, correct dose to use, time to use, medications and other foods not to use with current medications, avoidable side effects and what should be expected from treatment [7]. The community pharmacists also evaluate and monitor the medication effectiveness as well as ADRs to check the progress of treatment and prevent patient from ADRs [1].

As the collaboration between prescriber and pharmacist is important so does their perception towards each other role and as no such study was performed to investigate the perception of prescriber and pharmacist that is why to fill the gap this study was performed.

\section{METHODOLOGY}

\section{Study Design, Settings and Duration}

This study was questionnaire based, cross sectional survey conducted in Bolan Medical Complex Hospital (BMCH), Sandeman Provincial Hospital (SPH) and Community Pharmacies of Quetta, Pakistan from April to August 2019.

\section{Study Questionnaire}

For data collection specifically designed questionnaire was used and the questionnaire was developed after extensive literature review and with the help of some previous studies [8] [9] [10] [3]. The questionnaire comprised of 16 questions from 2 domains which were, traditional dispensing and traditional counselling role of community pharmacist apart from demographic characteristics. Each question was with response of 5-point Likert scale (comprised of Strongly Disagree, Disagree, Neutral, Agree and Strongly Agree) to which the respondents were asked to answer as per their agreement level.

\section{Validity/Reliability of Questionnaire}

Content and face validity were done by distributing the questionnaire to experts of Faculty of Pharmacy and the experts were asked for their views on worth, simplicity and significance. The experts were also asked about the questions they want to remove from the questionnaire. For content validity the experts were asked to list the questions in order of importance and relevance. For reliability Cronbach alpha test was applied, and the Cronbach alpha value of questionnaire was highly acceptable i.e. 0.889 [11].

\section{Study Population:}

The prescribers and pharmacists working in $\mathrm{BMCH}, \mathrm{SPH}$, community pharmacies and pharmaceutical firms were the study population.

\section{Sample Size}

To calculate the sample size for this study the Rao Soft calculator for sample size was used [12]. 95\% confidence interval, 5\% margin of error and 50\% Response distribution was selected to estimate the sample size, which resulted in total sample size of 385 . A drop out of $15 \%$ was added, a total of 450 Questionnaires were distributed and 428 were returned and added in the study.

\section{Sample Technique}

Non probability simple convenience sampling technique was used in this study because no exact database information was available regarding number of prescribers and pharmacists.

\section{Inclusion/Exclusion Criteria}

All the prescribers and pharmacists working in $\mathrm{BMCH}, \mathrm{SPH}$, Community Pharmacies and Pharmaceutical firms and willing to participate in study were included and all those participants who were not willing or not responded were excluded from study.

\section{Ethical Consideration}

The approval was taken from ethical committee of university of Balochistan, and consent, stating that the participation is voluntary, and participants can leave at any stage and their information will be kept confidential, was signed from participants before filling of questionnaire.

\section{Statistical Analysis}

To compute and analyze the data statistical package for social sciences version 21 were used (SPSS, V21). The descriptive statistics were applied, and results were computed as frequency and percentages. To test the association and significance among the variables Chi-square test was performed $(\mathrm{P}<0.05)$.

\section{RESULT}

\section{Demographic Characteristics}

Demographics characteristics are illustrated in table 1. Majority of respondents, $(n=139,32.5 \%)$, were having age ranges between $36-49$ years with male dominancy $(n=223$, $52.1 \%)$. Majority $(\mathrm{n}=242,56.5 \%)$ of respondents were prescribers while $(n=186,43.5 \%)$ were pharmacists. Doctor of Pharmacy (Pharm-D) was the highest qualification among majority of pharmacists $(n=151,35.3 \%)$ while the highest qualification among prescribers were FCPS $(n=98,22.9 \%)$. Specialty of majority $(n=106,24.8)$ of the respondents were community pharmacists with experience of $1-4$ years $(n=174$, 40.7). Majority $(n=151,35.3 \%)$ of the respondents were working at Bolan Medical Complex Hospital and $(n=107$, $25 \%$ ) of respondents were working as community pharmacists. 
Table 1: Demographic Characteristics of Participants

\begin{tabular}{|c|c|c|}
\hline Description & Frequency & Percentage (\%) \\
\hline $\begin{array}{l}\text { Age Group (Years) } \\
26-30 \\
31-35 \\
36-40 \\
41-45 \\
46 \text { and above }\end{array}$ & $\begin{array}{c}132 \\
125 \\
139 \\
27 \\
5\end{array}$ & $\begin{array}{c}30.8 \\
29.2 \\
32.5 \\
6.3 \\
1.2\end{array}$ \\
\hline $\begin{array}{l}\text { Gender } \\
\text { Male } \\
\text { Female }\end{array}$ & $\begin{array}{l}223 \\
205\end{array}$ & $\begin{array}{l}52.1 \\
47.9 \\
\end{array}$ \\
\hline $\begin{array}{l}\text { Occupation } \\
\text { Prescriber } \\
\text { Pharmacist } \\
\end{array}$ & $\begin{array}{l}242 \\
186 \\
\end{array}$ & $\begin{array}{l}56.5 \\
43.5 \\
\end{array}$ \\
\hline $\begin{array}{l}\text { Highest Qualification } \\
\text { FCPS } \\
\text { Pharm-D } \\
\text { MBBS } \\
\text { BDS } \\
\text { M-Phil } \\
\text { MCPS }\end{array}$ & $\begin{array}{c}98 \\
151 \\
62 \\
75 \\
35 \\
7\end{array}$ & $\begin{array}{l}22.9 \\
35.3 \\
14.5 \\
17.5 \\
8.2 \\
1.6\end{array}$ \\
\hline $\begin{array}{l}\text { Specialty } \\
\text { Hospital Pharmacist } \\
\text { Community Pharmacist } \\
\text { Medicine } \\
\text { Dentistry } \\
\text { Pediatrics } \\
\text { Gynecologist } \\
\text { Marketing Pharmacist }\end{array}$ & $\begin{array}{c}56 \\
106 \\
86 \\
96 \\
19 \\
41 \\
24\end{array}$ & $\begin{array}{c}13.1 \\
24.8 \\
20.1 \\
22.4 \\
4.4 \\
9.6 \\
5.6\end{array}$ \\
\hline $\begin{array}{l}\text { Experience (Years) } \\
1-4 \\
5-8 \\
9-12 \\
13-16 \\
17-20 \\
21-24\end{array}$ & $\begin{array}{c}174 \\
134 \\
78 \\
34 \\
5 \\
3\end{array}$ & $\begin{array}{c}40.7 \\
31.3 \\
18.2 \\
7.9 \\
1.2 \\
0.7\end{array}$ \\
\hline $\begin{array}{l}\text { Institute } \\
\text { Bolan Medical Complex Hospital } \\
\text { Sandeman Provincial Hospital } \\
\text { Community Pharmacy } \\
\text { Pharmaceutical Company }\end{array}$ & $\begin{array}{c}151 \\
146 \\
107 \\
24\end{array}$ & $\begin{array}{c}35.3 \\
34.1 \\
25.0 \\
5.6\end{array}$ \\
\hline $\begin{array}{l}\text { Current Position } \\
\text { House Officer } \\
\text { Assistant Professor } \\
\text { Associate Professor } \\
\text { Registrar } \\
\text { Post-Graduate } \\
\text { Community Pharmacist } \\
\text { Medical Representative } \\
\text { Hospital Pharmacist } \\
\text { Dental Surgeon } \\
\text { Medical Officer }\end{array}$ & $\begin{array}{c}33 \\
20 \\
10 \\
23 \\
37 \\
107 \\
24 \\
55 \\
69 \\
50\end{array}$ & $\begin{array}{c}7.7 \\
4.7 \\
2.3 \\
5.4 \\
8.6 \\
25.0 \\
5.6 \\
12.9 \\
16.1 \\
11.7\end{array}$ \\
\hline
\end{tabular}

\section{Traditional Dispensing Role of Community Pharmacist}

Traditional dispensing role of community pharmacists is illustrated in Table 2. Majority $(n=218,50.9 \%)$ of participants strongly agreed that drugs should not be dispensed without Pharmacist while majority agreed on roles of community pharmacists that are availability of medicines $(n=262,61.2 \%)$, make/ prepare drug list used in community setting $(n=281$, $65.7 \%$ ), purchase and stock drug used in community setting
( $\mathrm{n}=163,38.1 \%$ ), technical component of dispensing including counting, preparing and measuring of medicines/ dose $(n=135$, $31.5 \%)$, labelling of medicines $(n=237,55.4 \%)$, dispense medicines services throughout the day $(n=118,27.6 \%)$, maintain manual record of all patients/ prescriptions $(n=212$, $49.5 \%$ ) and maintain computer record/ profile of all patients/ prescriptions $(\mathrm{n}=188,43.9 \%)$. 
Table 2: Traditional Dispensing Role of Community Pharmacist

\begin{tabular}{|c|c|c|c|c|c|}
\hline Description & $\begin{array}{c}\text { Strongly } \\
\text { Disagree } \\
\text { F (\%) }\end{array}$ & $\begin{array}{c}\text { Disagree } \\
\text { F }(\%)\end{array}$ & $\begin{array}{c}\text { Neutral } \\
\text { F (\%) }\end{array}$ & $\begin{array}{l}\text { Agree } \\
\text { F (\%) }\end{array}$ & $\begin{array}{c}\text { Strongly } \\
\text { Agree } \\
\text { F (\%) }\end{array}$ \\
\hline Availability of medicines (Both prescribed and OTC) & $2(0.5)$ & $45(10.5)$ & $37(8.6)$ & $262(61.2)$ & $82(19.2)$ \\
\hline Make/ prepare drug list used in community setting & ---- & $\begin{array}{l}11 \\
(2.6)\end{array}$ & $\begin{array}{c}43 \\
(10.0)\end{array}$ & $\begin{array}{c}281 \\
(65.7)\end{array}$ & $93(21.7)$ \\
\hline Purchase and stock drug used in community setting & ---- & $\begin{array}{c}35 \\
(8.2)\end{array}$ & $\begin{array}{c}68 \\
(15.9)\end{array}$ & $\begin{array}{c}163 \\
(38.1)\end{array}$ & $162(37.9)$ \\
\hline $\begin{array}{l}\text { Technical component of dispensing including counting, preparing } \\
\text { and measuring of medicines/ dose }\end{array}$ & ---- & $11(2.6)$ & $58(13.6)$ & $135(31.5)$ & $224(52.3)$ \\
\hline Labelling of medicines & ---- & $8(1.9)$ & $41(9.6)$ & $237(55.4)$ & $142(33.2)$ \\
\hline $\begin{array}{l}\text { Dispense medicines services throughout the day (Minimum } 16 \\
\text { hours) }\end{array}$ & $5(1.2)$ & $83(19.4)$ & $45(10.5)$ & $118(27.6)$ & $177(41.4)$ \\
\hline No drug dispensing without pharmacist & ---- & $82(19.2)$ & $19(4.4)$ & $109(25.5)$ & $218(50.9)$ \\
\hline Maintain manual record of all patients/ prescriptions & $1(0.2)$ & $25(5.8)$ & $22(5.1)$ & $212(49.5)$ & $168(39.3)$ \\
\hline Maintain computer record/ profile of all patients/ prescriptions & $30(7)$ & $41(9.6)$ & $23(5.4)$ & $188(43.9)$ & $146(34.1)$ \\
\hline
\end{tabular}

Traditional Counselling Role of Community Pharmacist Traditional dispensing role of community pharmacists is illustrated in Table 3. Majority of the participants agreed that the community pharmacist's role is counselling the patients for medications $(\mathrm{n}=234,54.7 \%)$, counselling patients for risk/ benefit of prescription $(n=197,46 \%)$, counselling regarding ADR/ side effects of the prescription $(n=203,47.4 \%)$ and educate patients for drug misuse/ abuse $(198,46.3 \%)$. Majority $(\mathrm{n}=114,26.6 \%)$ of the participants disagreed on the community pharmacist's role that they can educate patients for other diseases while majority of the participants neither agreed nor disagreed regarding the community pharmacist's role that they can educate patients for his/ her current disease condition $(\mathrm{n}=126,29.4 \%)$ and educate patients for family planning $(\mathrm{n}=123,28.7)$.

Table 3: Traditional Counselling Role of Community Pharmacist

\begin{tabular}{|c|c|c|c|c|c|}
\hline Description & $\begin{array}{c}\text { Strongly } \\
\text { Disagree } \\
\text { F }(\%) \\
\end{array}$ & $\begin{array}{c}\text { Disagree } \\
\text { F }(\%) \\
\end{array}$ & $\begin{array}{l}\text { Neutral } \\
\text { F }(\%) \\
\end{array}$ & $\begin{array}{l}\text { Agree } \\
\text { F (\%) } \\
\end{array}$ & $\begin{array}{c}\text { Strongly } \\
\text { Agree } \\
\text { F (\%) } \\
\end{array}$ \\
\hline Counselling patients for prescription/ OTC medicines & ---- & $9(2.1)$ & $64(15)$ & $\begin{array}{c}234 \\
(54.7)\end{array}$ & $121(28.3)$ \\
\hline $\begin{array}{l}\text { Counselling patients for risk/ benefit of prescription/ OTC } \\
\text { medicines }\end{array}$ & $10(2.3)$ & $67(15.7)$ & $46(10.7)$ & $\begin{array}{l}197 \\
(46)\end{array}$ & $108(25.2)$ \\
\hline $\begin{array}{l}\text { Counselling regarding ADR/ side effects of the prescription/ } \\
\text { OTC medicines }\end{array}$ & $8(1.9)$ & $34(7.9)$ & $40(9.3)$ & $\begin{array}{c}203 \\
(47.4)\end{array}$ & $143(33.4)$ \\
\hline Educate patients for his/ her current disease condition & $8(1.9)$ & $81(18.9)$ & $\begin{array}{c}126 \\
(29.4)\end{array}$ & $\begin{array}{c}102 \\
(23.8)\end{array}$ & $111(25.9)$ \\
\hline Educate patients for other diseases & $67(15.7)$ & $114(26.6)$ & $\begin{array}{c}102 \\
(23.8) \\
\end{array}$ & $\begin{array}{c}72 \\
(16.8) \\
\end{array}$ & $73(17.1)$ \\
\hline Educate patients for family planning & ---- & $150(35)$ & $\begin{array}{c}123 \\
(28.7)\end{array}$ & $\begin{array}{c}81 \\
(18.9)\end{array}$ & $74(17.3)$ \\
\hline Educate patients for drug misuse/ abuse & $31(7.2)$ & $5(1.2)$ & $45(10.5)$ & $\begin{array}{c}198 \\
(46.3)\end{array}$ & $149(34.8)$ \\
\hline
\end{tabular}

\section{Perception of Participants}

Perception of participants are illustrated in Table 4. Majority of the participants had positive perception regarding traditional dispensing $(n=386,90.2 \%)$, traditional counselling $n=314,73.4 \%)$ role of community pharmacist. 
Table 4: Perception of Participants

\begin{tabular}{|l|c|c|}
\hline Description & $\begin{array}{c}\text { Positive } \\
\text { Perception } \\
\text { F (\%) }\end{array}$ & $\begin{array}{c}\text { Negative } \\
\text { Perception } \\
\text { F (\%) }\end{array}$ \\
\hline Traditional Dispensing & $386(90.2)$ & $42(9.8)$ \\
\hline Traditional Counselling & $314(73.4)$ & $114(26.6)$ \\
\hline Overall Score & $424(78.3)$ & $4(21.7)$ \\
\hline
\end{tabular}

Comparison of Demographic Characteristics with Role of Community Pharmacist (Traditional Dispensing Role) Occupation, highest qualification, experience, current working position and specialty were significantly associated $(\mathrm{P}<0.05)$ with perception regarding traditional dispensing role of community pharmacist.

Table 5: Comparison of Demographic Characteristics with Role of Community Pharmacist (Traditional Dispensing Role)

\begin{tabular}{|c|c|c|c|}
\hline Description & $\begin{array}{c}\text { Positive } \\
\text { F (\%) } \\
\end{array}$ & $\begin{array}{c}\text { Negative } \\
\text { F }(\%)\end{array}$ & P-Test \\
\hline \multicolumn{4}{|l|}{ Occupation } \\
\hline $\begin{array}{l}\text { Traditional Dispensing } \\
\text { Prescriber } \\
\text { Pharmacist }\end{array}$ & $\begin{array}{l}200(82.6) \\
186(100))\end{array}$ & $42(17.4)$ & 0.001 \\
\hline \multicolumn{4}{|l|}{ Highest Qualification } \\
\hline $\begin{array}{l}\text { Traditional Dispensing } \\
\text { FCPS } \\
\text { Pharm-D } \\
\text { MBBS } \\
\text { BDS } \\
\text { M-Phil } \\
\text { MCPS }\end{array}$ & $\begin{array}{l}77(18.0) \\
151(35.3) \\
48(11.2) \\
68(15.9) \\
35(8.2) \\
7(1.6) \\
\end{array}$ & $\begin{array}{c}21(4.9) \\
---- \\
14(3.3) \\
7(1.6) \\
---- \\
---- \\
\end{array}$ & 0.001 \\
\hline \multicolumn{4}{|l|}{ Specialty } \\
\hline $\begin{array}{l}\text { Traditional Dispensing } \\
\text { Hospital Pharmacist } \\
\text { Community Pharmacist } \\
\text { Medicine } \\
\text { Dentistry } \\
\text { Pediatrics } \\
\text { Gynecologist } \\
\text { Marketing Pharmacist }\end{array}$ & $\begin{array}{c}54(12.6) \\
104(24.3) \\
1(0.2) \\
42(9.8) \\
6(1.4) \\
24(5.6) \\
24(5.6) \\
\end{array}$ & $\begin{array}{c}2(0.5) \\
2(0.5) \\
85(19.9) \\
54(12.6) \\
13(3.0) \\
17(4.0) \\
----\end{array}$ & 0.001 \\
\hline \multicolumn{4}{|l|}{ Experience } \\
\hline $\begin{array}{l}\text { Traditional Dispensing } \\
\text { 1-4 Years } \\
\text { 5-8 Years } \\
\text { 9-12 Years } \\
\text { 13-16 Years } \\
\text { 17-20 years } \\
\text { 21-24 years }\end{array}$ & $\begin{array}{l}162(37.9) \\
125(29.2) \\
68(15.9) \\
23(5.4) \\
5(1.2) \\
3(0.7) \\
\end{array}$ & $\begin{array}{c}12(2.8) \\
9(2.1) \\
10(2.3) \\
11(2.6) \\
---- \\
---- \\
\end{array}$ & 0.001 \\
\hline \multicolumn{4}{|l|}{ Current Working Position } \\
\hline $\begin{array}{l}\text { Traditional Dispensing } \\
\text { House Officer } \\
\text { Assistant Professor } \\
\text { Associate Professor } \\
\text { Registrar } \\
\text { Post Graduate } \\
\text { Community Pharmacist } \\
\text { Medical Representative } \\
\text { Hospital Pharmacist } \\
\text { Dental Surgeon } \\
\text { Medical Officer } \\
\end{array}$ & $\begin{array}{c}26(6.1) \\
15(3.5) \\
7(1.6) \\
20(4.7) \\
28(6.5) \\
107(25.0) \\
24(5.6) \\
55(12.9) \\
66(15.4) \\
38(8.9) \\
\end{array}$ & $\begin{array}{c}7(1.6) \\
5(1.2) \\
3(0.7) \\
3(0.7) \\
9(2.1) \\
---- \\
---- \\
--- \\
3(0.7) \\
12(2.8) \\
\end{array}$ & 0.001 \\
\hline
\end{tabular}

Comparison of Demographic Characteristics with Role of Community Pharmacist (Traditional Counselling Role) 
Occupation, highest qualification, experience, current working position and specialty were significantly associated $(\mathrm{P}<0.05)$ with perception regarding traditional counselling role of community pharmacist.

Table 6: Comparison of Demographic Characteristics with Role of Community Pharmacist (Traditional Counselling Role)

\begin{tabular}{|c|c|c|c|}
\hline Description & $\begin{array}{c}\text { Positive } \\
\text { F }(\%)\end{array}$ & $\begin{array}{c}\text { Negative } \\
\text { F }(\%)\end{array}$ & P-Test \\
\hline \multicolumn{4}{|l|}{ Occupation } \\
\hline $\begin{array}{l}\text { Traditional Counselling } \\
\text { Prescriber } \\
\text { Pharmacist }\end{array}$ & $\begin{array}{c}132(54.5) \\
182(97.8) \\
\end{array}$ & $\begin{array}{c}110(45.5) \\
4(2.2) \\
\end{array}$ & 0.001 \\
\hline \multicolumn{4}{|l|}{ Highest Qualification } \\
\hline $\begin{array}{l}\text { Traditional Counselling } \\
\text { FCPS } \\
\text { Pharm-D } \\
\text { MBBS } \\
\text { BDS } \\
\text { M-Phil } \\
\text { MCPS }\end{array}$ & $\begin{array}{c}37(8.6) \\
147(34.3) \\
23(5.4) \\
65(15.2) \\
35(8.2) \\
7(1.6) \\
\end{array}$ & $\begin{array}{c}61(14.3) \\
4(0.9) \\
39(9.1) \\
10(2.3) \\
---- \\
----\end{array}$ & 0.001 \\
\hline \multicolumn{4}{|l|}{ Specialty } \\
\hline $\begin{array}{l}\text { Traditional Counselling } \\
\text { Hospital Pharmacist } \\
\text { Community Pharmacist } \\
\text { Medicine } \\
\text { Dentistry } \\
\text { Pediatrics } \\
\text { Gynecologist } \\
\text { Marketing Pharmacist }\end{array}$ & $\begin{array}{c}56(13.1) \\
106(24.8) \\
33(7.7) \\
80(18.7) \\
15(3.5) \\
4(0.9) \\
20(4.7) \\
\end{array}$ & $\begin{array}{c}--- \\
--- \\
53(12.4) \\
16(3.7) \\
4(0.9) \\
37(8.6) \\
4(0.9) \\
\end{array}$ & 0.001 \\
\hline \multicolumn{4}{|l|}{ Experience } \\
\hline $\begin{array}{l}\text { Traditional Counselling } \\
\text { 1-4 Years } \\
\text { 5-8 Years } \\
\text { 9-12 Years } \\
\text { 13-16 Years } \\
\text { 17-20 years } \\
\text { 21-24 years } \\
\end{array}$ & $\begin{array}{l}143(33.4) \\
95(22.2) \\
50(11.7) \\
23(5.4) \\
2(0.5) \\
1(0.2) \\
\end{array}$ & $\begin{array}{l}31(7.2) \\
39(9.1) \\
28(6.5) \\
11(2.6) \\
3(0.7) \\
2(0.5)\end{array}$ & 0.005 \\
\hline \multicolumn{4}{|l|}{ Current Working Position } \\
\hline $\begin{array}{l}\text { Traditional Counselling } \\
\text { House Officer } \\
\text { Assistant Professor } \\
\text { Associate Professor } \\
\text { Registrar } \\
\text { Post-Graduate } \\
\text { Community Pharmacist } \\
\text { Medical Representative } \\
\text { Hospital Pharmacist } \\
\text { Dental Surgeon } \\
\text { Medical Officer }\end{array}$ & $\begin{array}{c}20(4.7) \\
10(2.3) \\
--- \\
12(2.8) \\
17(4.0) \\
107(25.0) \\
20(4.7) \\
55(12.9) \\
61(14.3) \\
12(2.8)\end{array}$ & $\begin{array}{c}13(3.0) \\
10(2.3) \\
10(2.3) \\
11(2.6) \\
20(4.7) \\
---- \\
4(0.9) \\
--- \\
8(1.9) \\
38(8.9)\end{array}$ & 0.001 \\
\hline
\end{tabular}

\section{DISCUSSION}

Pharmacist play an important role in the Healthcare system by utilizing it diverse skills in various domains within the Pharmacy and Healthcare system. Community pharmacists are public healthcare providers. They dispense medicines or, when ordered, sell them without prescription. In addition to ensure dispensing of quality products, their professional services include patient counselling at time of prescription filling. They relationships with other health professionals and primary healthcare.

The prescribers had positive perception regarding traditional roles of dispensing and counselling of community pharmacists that they cover counselling of patients at the time of dispensing of prescription and supply traditional medicines and dispense them accordingly. This is similar to study conducted in Jordon where author showed that prescribers were having positive perception and were broadly recognizing the traditional role of community pharmacists including educating the patients [13] and according to the study conducted in New Zealand $60 \%$ of prescribers had positive perception regarding dispensing role of community pharmacists [14]. The study conducted in 
Macau concluded that the both pharmacists and prescribers agreed on medication dispensing role pharmacist [15]. Another study showed that community pharmacists continually in the provision of patient counselling and health education services for patients at community level [16]

Current study results explained regarding the counselling role of community pharmacists. That may include various domains within the counselling like pharmacist-provided medication counselling is important for improving medication use, preventing medication errors and ensuring that the desired outcomes can be achieved. Pharmacists in public health services include smoking cessation counselling too. Current study had showed prescribers and pharmacists both agreed on counselling roles this is consistent with study conducted in New Zealand concluding Eight-five percent of prescribers and pharmacists agreed on counselling role of community pharmacists [14]. This Study concluded that the prescribers and pharmacists agreed on counselling role of community pharmacists while according to study conducted in Jordon $92 \%$ of the pharmacists and $59 \%$ of prescribers agreed on counselling role of community pharmacists [13].

The patient education is prime consideration with the sphere of community pharmacist. Patient education is important factor in determining the patient-oriented role of community pharmacist to educate the patient on lifestyle modifications, and monitoring medication adherence which ultimately lessen the disease burden on an individual and on community. This study concluded that both pharmacists and prescribers had positive perception regarding the role of community pharmacist as patient education similar to study conducted in Macau concluded that both pharmacists and prescribers had positive perception regarding educating the patient role [15]. Study conducted in Tehran concluded that $60.3 \%$ of prescribers had positive perception regarding educating the patient role of community pharmacist [17]. A study conducted in United States concluded that $65.1 \%$ of prescribers had positive perception regarding educating the patients [18].

Pharmacists recognize the importance of documenting patient care. As a rule of thumb Community. Pharmacists are the health professionals most accessible to the public. The study finding showed that the pharmacists and prescribers agreed that the community pharmacists have role in maintaining the record of patients and prescriptions, the study conducted in New Zealand also resulted in agreement of prescribers and pharmacists regarding community pharmacist's role of maintaining record [14]. Same results were found with the study conducted Macau having same results [15].

This study resulted that the prescribers were agreed regarding community pharmacist's role in maintaining the profile of patients and similar results were obtained from study conducted in California [19]. According to this study $61.2 \%$ of participants agreed that the community pharmacists had role in availability of medicines and according to study conducted in Punjab, Pakistan $83.3 \%$ of prescribers showed similar agreement [20].

This study concluded that prescribers had positive perception regarding traditional counselling of role of community pharmacists and according to study conducted in Karnataka, India $67 \%$ of prescribers showed positive perception [21] similar to study conducted in Macau concluded positive perception regarding traditional counselling role of community pharmacist [15]. The study conducted in Macao resulted in pharmacist's positive perception regarding counselling (90\%) and providing medication related information to patients (85\%) [22]. Similarly, a study conducted in Tehran concluded that $90 \%$ prescribers had positive perception regarding community pharmacist's information providing role [17].

This study resulted in positive perception from prescribers and pharmacists regarding OTC medication counselling to patients similar study conducted in Macau concluded positive perception regarding counselling of OTC medication to patient by community pharmacist [15]. Study conducted in United States concluded that $63.4 \%$ of prescribers had positive perception regarding OTC medication information providing role [18].

\section{CONCLUSION:}

This study concluded that the pharmacists and prescribers had positive perception regarding traditional role of community pharmacists that is dispensing, and counselling role and further studies should be conducted to assess extended role of community pharmacists.

\section{Declaration:}

Authors declare no conflict of interest for this study.

\section{REFERENCES}

1. World Health Organization, Joint FIP/WHO Guidelines on Good Pharmacy Practice: Standards for quality of pharmacy services. Geneva 2011. 2011, Report.

2. Alan J, L Jessica, L. Barry. Utility of a questionnaire to measure physician pharmacist collaborative relationship. J Am Pharm Assoc, 2006. 46(4): 453-458.

3. Jeff Klein. Types of Pharmacists,. 2007 [cited 2019; Available from: http://pharmacy-schools.us/articles/typesof-pharmacists/.

4. Association of Graduate Careers Advisory Services. Community pharmacist. 2019 [cited 2019; Available from: profiles/community-pharmacist.

5. Leah Gilbert, To diagnose, prescribe and dispense: whose right is it? The ongoing struggle between pharmacy and medicine in South Africa. Current Sociology, 2001. 49(3): 97-118.

6. Wiedenmayer K, et al., Developing pharmacy practice: a focus on patient care: handbook. 2006, Geneva: World Health Organization.

7. Worley MM, et al., Pharmacists' and patients' roles in the pharmacist-patient relationship: are pharmacists and patients reading from the same relationship script? Research in Social and Administrative Pharmacy, 2007. 3(1):47-69.

8. Lexico. Healthcare. 2019 [cited 2019; Available from: https://www.lexico.com/en/definition/healthcare.

9. Azhar S, Hassali MA, Ibrahim MM. Perceptions of hospital pharmacist's role in Pakistan's healthcare system: a crosssectional survey. Tropical J Pharm Res. 2011.10(1).

10. Barr V, et al., The expanded chronic care model. Hosp Q, 2003.7(1):73-82.

11. Gliem, J.A. and R.R. Gliem. Calculating, interpreting, and reporting Cronbach's alpha reliability coefficient for 
Likert-type scales. 2003. Midwest Research-to-Practice Conference in Adult, Continuing, and Community

12. Raosoft I, Sample size calculator. Available from: www. raosoft com/samplesize, 2004.

13.Tahaineh LM, et al., Perceptions, experiences, and expectations of physicians in hospital settings in Jordan regarding the role of the pharmacist. Research in Social and Administrative Pharmacy, 2009. 5(1):63-70.

14.Bryant LJ, et al., General practitioners' and pharmacists' perceptions of the role of community pharmacists in delivering clinical services. Research in Social and Administrative Pharmacy, 2009. 5(4):347-362.

15.Lo U, H Hu, C.O.L. Ung. Physicians' and pharmacists' experience and expectations of the roles of pharmacists: insights into hospital setting in Macau. Tropical Journal of Pharmaceutical Research, 2013. 12(6):1077-1085.

16.Haile K., et al., The Role of Community Pharmacists in Patient Counselling and Health Education: A Survey of Their Knowledge and Level of Involvement in Relation to Type 2 Diabetes Mellitus. Value in Health, 2017. 20(9): A496.

17.Alipour, F., F. Peiravian, and G. Mehralian, Perceptions, experiences and expectations of physicians regarding the role of pharmacists in low-income and middle-income countries: the case of Tehran hospital settings. BMJ open, 2018. 8(2):e019237.

18.Ranelli, P.L. and J. Biss, Physicians' perceptions of communication with and responsibilities of pharmacists. Journal of the American Pharmaceutical Association (1996), 2000. 40(5):625-630.

19.Smith, W.E., MD Ray, D.M. Shannon. Physicians' expectations of pharmacists. American journal of healthsystem pharmacy, 2002. 59(1):50-57.

20. Azhar S, M. Hassali, M. Ibrahim. Doctors' perception and expectations of the role of the pharmacist in Punjab, Pakistan. Tropical J Pharm Research, 2010. 9(3).

21.Adepu, R. and B. Nagavi, General practitioners' perceptions about the extended roles of the community pharmacists in the state of Karnataka: A study. Indian J Pharm Sci. 2006. 68(1):36.

22. Ung COL, et al., Community pharmacists' understanding, attitudes, practice and perceived barriers related to providing pharmaceutical care: a questionnaire-based survey in Macao. Tropical Journal of Pharmaceutical Research, 2016. 15(4):847-854.

Cite article as: Saood M, Haq NU, Nasim A, Shah Y, Tahir M. Perception of Prescribers and Pharmacists Regarding Traditional role of Community Pharmacists in Quetta, Pakistan. Res Pharm Healt Sci. 2019;5(4):197-204. doi:

https://doi.org/10.32463/RPHS.2019.v05i04.02. 